\title{
WEB-BASED RPS MANAGEMENT INFORMATION SYSTEM (SEMESTER LESSON PLAN) USING WATERFALL MODEL
}

\author{
Muhammad Nugraha1*); Muhammad Lulu Latif Usman²; Tiawan³ \\ Prodi Teknologi Rekayasa Perangkat Lunak \\ Politeknik Enjinering Indorama \\ https://pei.ac.id \\ nugraha@pei.ac.id 1*), lulu.latif@pei.ac.id 2, tiawan@pei.ac.id 3
}

(*) Corresponding Author

\begin{abstract}
Semester Learning Plan (RPS) is a learning planning document prepared as a guide for lecturers and students in carrying out teaching and learning activities on campus for one semester. RPS was made to guide lecturers and students in the learning process so that the material taught is following the learning outcomes set by the study program. To meet and adjust the needs of graduate users and the development of science and technology, the RPS must be regularly reviewed and updated if there are changes in teaching materials that are no longer following current conditions. However, what often becomes a problem is that there is no documented process for changing the RPS content regarding the reasons and which parts have changed so that the RPS change process cannot be carried out at will and when audited there is a history of changing the data. Because of these problems, this research will design and build a webbased RPS management information system that can assist study programs in documenting RPS changes and making it easier for users to access the changed content. The system development method used in this study uses the waterfall method, and for its design using UML (Unified Modeling Language). The final result of this research is a web-based RPS management information system using the Codeigniter 4 framework which can make it easier for managers and users to obtain RPS information.
\end{abstract}

Keywords: system; information; syllabus; web

Intisari-Rencana Pembelajaran Semester (RPS) adalah dokumen perencanaan pembelajaran yang disusun sebagai pedoman bagi dosen dan mahasiswa dalam melaksanakan kegiatan belajar mengajar di kampus selama satu semester. RPS dibuat untuk memberi pedoman kepada dosen dan mahasiswa dalam proses pembelajaran agar materi yang diajarkan sesuai dengan capaian pembelajaran yang telah ditetapkan oleh program studi. RPS. Untuk memenuhi dan menyesuaikan kebutuhan pengguna lulusan dan perkembangan IPTEK maka RPS harus secara rutin di review dan di update jika ada perubahan materi ajar yang sudah tidak sesuai lagi dengan kondisi terkini. Akan tetapi yang sering menjadi masalah adalah tidak terdokumentasinya proses perubahan konten RPS mengenai alasan dan bagian mana saja yang mengalami perubahan agar proses perubahan RPS tidak dapat di lakuan sesukanya dan ketika di audit terdapat history peerubahan datanya. Oleh karena permasalahan tersebut maka pada penelitian ini akan di rancang dan di bangung sistem informasi manajemen RPS berbasis web yang dapat membantu prodi dalam mendokumentasikan perubahan RPS dan mempermudah user dalam mengakses konten perubahannya. Metode pembangunan sistem yang digunakan pada penelitian ini menggunakan metode waterfall, dan untuk perancangannya menggunakan UML (Unified Modelling Languange). Hasil akhir dari penelitian ini berupa sistem informasi manajemen RPS berbasis web dengan menggunakan framework Codeigniter 4 yang dapat mempermudah pengelola dan user dalam mendapatkan informasi RPS.

Kata Kunci: sistem; infromasi; rps; web

\section{INTRODUCTION}

Semester Learning Plan (RPS) is a learning planning document prepared as a guide for lecturers and students in carrying out teaching and learning activities on campus for one semester (Government Regulations, 2013; Regulation of the Minister of Research Technology and Higher Education, 2016). The benefit of having RPS is to guide lecturers and students in the learning process so that the material taught is by the learning outcomes set by the study program (Sagala, 2013). In the preparation of the RPS, the more quality the RPS will produce more effective and efficient learning and can increase the positive influence in the learning undertaken (Muhsinin \& Fatmawati, 2020; Nurdin, 2018; Sitepu \& Lestari, 2018; Yunianto, 2021). To meet and adapt to the needs of graduate users and the development of science and technology, this RPS must be regularly reviewed 
and updated if there are changes in teaching materials that are no longer in current conditions (APTIKOM, 2018; Nurdin, 2018). On the review process of RPS when there is content that must be updated or changed usually, the compilers of the RPS do not record ad documented the list of changes and the reasons for the changes as a history of changes (Regulation of the Minister of Education, 2014). It is very important to document the history of this change to trace the change process from time to time so that the RPS change process is not carried out carelessly without a clear basis.

Web-based information systems are one of the technologies that are currently widely used by various agencies for processing data and information. Because by using web-based information system technology, data and information management becomes more effective and efficient (Husaini, 2019). Therefore, by utilizing information system technology, access to data becomes easier, faster, and more accurate. Management of RPS using a web-based information system will greatly help both the lecturer as a user and the study program as the manager. Managers will find it easier to make repairs and document the history of repairs and the lecturers will also easily access them anytime and anywhere.

Research that has been carried out related to the development of a Study Learning Plan or RPS includes research from Indrawan (2019); Wicaksono (2018); Nurdin (2018); Indera, Saleh, and Kristian (2020); Syafarina, and Setiawan (2019). In the research conducted by Indrawan, it is more focused on the design, distribution, and evaluation of the curriculum, while the history of content changes from the RPS evaluation does not yet exist, so that the process of changes made in the RPS cannot be tracked as why it changed and on what basis the changes were made (Indrawan, 2019). A similar system was developed in the research conducted by Wicaksono, where the research was supported by other research conducted by Marthasari and Hayatin by conducting usability testing with an eligibility level of $72.8 \%$ (Marthasari \& Hayatin, 2017; Wicaksono, 2015). The Wicaksono research system can only make RPS which is then generated into the existing RPS format in the system, and no system distributes the RPS that has been made to other users such as higher education policymakers or students (Wicaksono, 2015). In the research conducted by Nurdin, the management of RPS on the system that is built is still manual, meaning that the lecturer must first compile the RPS and send it to the operator in soft file in pdf format then after that the operator uploads the file to the web (Nurdin, 2018). The same system was built on Indera, Saleh, and Kristian where RPS was sent in soft file in word or pdf format so that there was still no system that could not standardize the RPS format (Indera, Saleh, \& Kristian, 2020). In the research conducted by Syafarina and Setiawan, the system was created using web input where the system was able to standardize in the RPS format, but there was a feature to review the RPS and the system could not record data on changes to the RPS that had been done (Syafarina \& Setiawan, 2019). Of the 4 studies that have been carried out, this study has the advantage that the system can enter RPS component data where the format is regulated by the system so that the format that will be made by all lecturers will be the same. Also, in this study, the system can record changes in RPS data so that the system can track changes that have been made. Because of this, this research will design and build a web-based RPS management information system that can be accessed by users easily and quickly. One of the features that will be different in this system is the feature that tracks changes in the contents of the RPS. With this feature, it is easier for managers or assessors to find out the history of changes that have occurred on the basis and reasons for what changes were made. so that the process of changing the RPS is not carried out arbitrarily according to the wishes of the lecturer or manager. In this study, the method that will be used is the waterfall and the design method using UML.

\section{MATERIALS AND METHODS}

The research method used is the quantitative method of pre-experimental designs one-shot case study with software development using the Waterfall Model (Gharajeh, 2019; Kramer, 2018; Sarosa, 2017). The study used the dependent variable by ignoring the independent variable where the variables that had been treated were then observed (Sugiyono, 2010). Analysis and testing using Unit Testing and Acceptance Testing with the Black-Box Testing technique. Unit Testing is used to test a function of the unit whether it is appropriate or not, while Acceptance Testing is used whether the application is by user needs (Jorgensen, 2018). The Black-Box Testing technique is a test by testing application functions to find various errors that arise from a system itself (Roman, 2018). Waterfall Model as a self-developed software development model has stages consisting of:

\section{A. Needs Analysis}

At this stage, the researchers identified the problem and collect data and information by observation and study of literature (Rasimin, 2018) which was later adapted to the needs of users in the field. 


\section{B. System Design}

After completing the needs analysis, the next step is to design the system that will be implemented. At this stage, the researcher will design the system starting from the database design represented by ERD, the system design using the UML model, and finally, the user interfaces design using an application mockup.

\section{Implementation}

This stage is the stage of coding or making applications. The application implementation process must refer to the results of the system design that has been made previously. At this stage, what is done is implementing ERD into a physical table in the database, creating a display based on the mockup that has been designed, and coding based on the design of the UML at the system design stage.

\section{Testing}

Testing conducted focuses on testing the system in terms of functionality and logic. This testing stage aims to ensure that the system runs according to design and needs. This stage also aims to minimize errors and mismatches in the inputoutput on the system.

\section{E. Maintenance}

Maintenance is carried out after the system is finished and has passed the testing process. This stage is quite important considering the development of technology and the needs of users who will always be up to date at any time. Maintenance is carried out when there are bugs or additional features that are needed at a later date.

\section{RESULT AND DISCUSSION}

Based on the results of the needs analysis that has been carried out, a web-based RPS management information system design can be designed and implemented with the following results:

\section{A. Needs Analysis}

Based on the analysis of the functional requirements of the system from users, it can be described as follows: The system can log in, logout, and validate, can manage study program data, can manage lecturer data, can manage course data, can manage CP Study Program data, can manage detailed CPP data MK, can manage CPMK data, can manage data on study materials, can manage reference data, can manage RPS data, can manage history data, can view CPMK data, can view data on study materials, can see reference data, can see RPS data, can see CP Prodi data, can see course data. These functional needs are outlined in the Usecase Diagram which is an overview of system functionality or business processes from the user's perspective (Munawar, 2018). The starting point in making use-case diagrams is seen from how users use the system. The use case diagram of the system to be built is as in Figure 1 below.

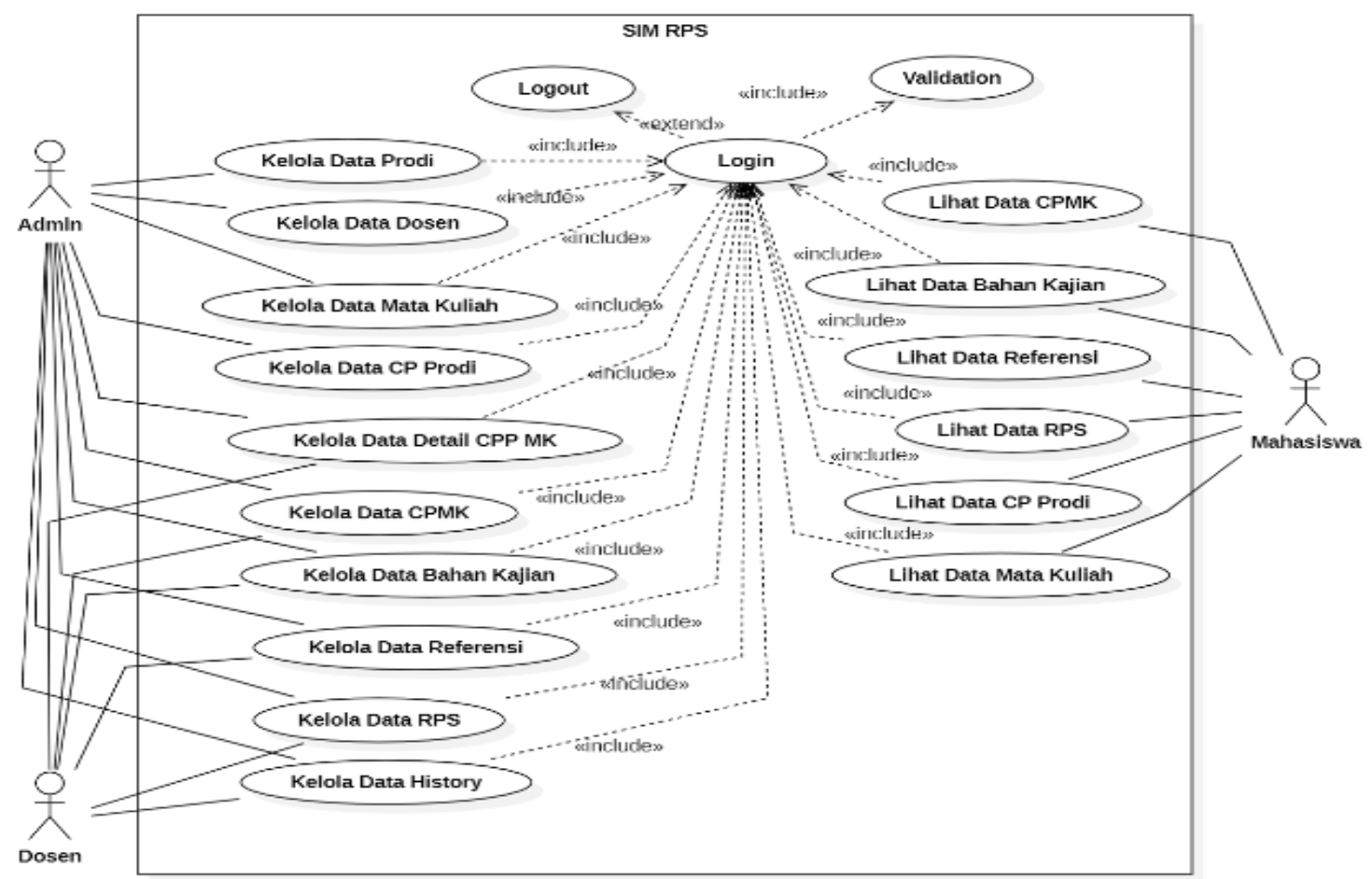

Figure 1. Use Case Diagram Management Information System of RPS 


\section{B. System Design}

1. Modelling System Design

System modeling in addition to using use cases in analyzing further needs uses Activity Diagrams, Classes, and Sequence diagrams.

\section{a. Activity Diagram}

The activity diagram shows the program flow that occurs between the user and the running system (Sugiarti, 2013). Each process in the system will be described with an activity diagram. Figure 2 below shows the data management activity diagram, where this activity diagram illustrates the activity of the entire data management process in the use case diagram. The activity diagram shows the program flow that occurs between the user and the running system (Sugiarti, 2013). Each process in the system will be described with an activity diagram. Figure 2 below shows the data management activity diagram, where this activity diagram illustrates the activity of the entire data management process in the use case diagram.

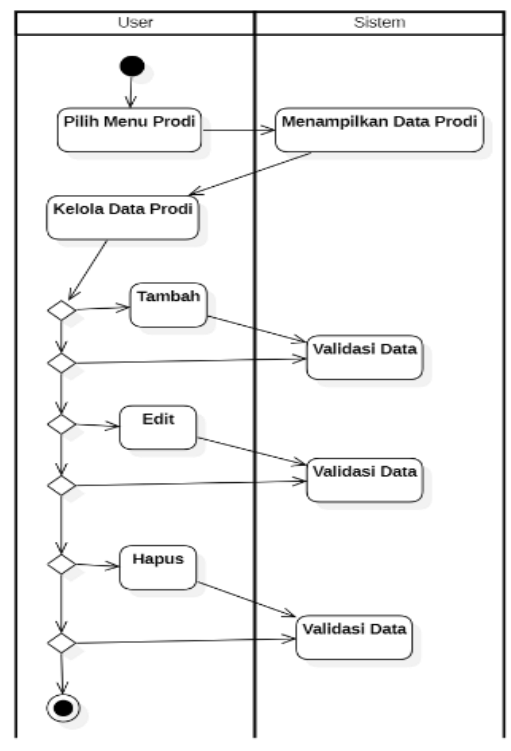

Figure 2. Activity Diagram Data Management

\section{b. Class Diagram}

The class diagram as shown in Figure 3 below illustrates the class structure or blueprint of the system to be built. The existing classes can represent something that is handled by the system.

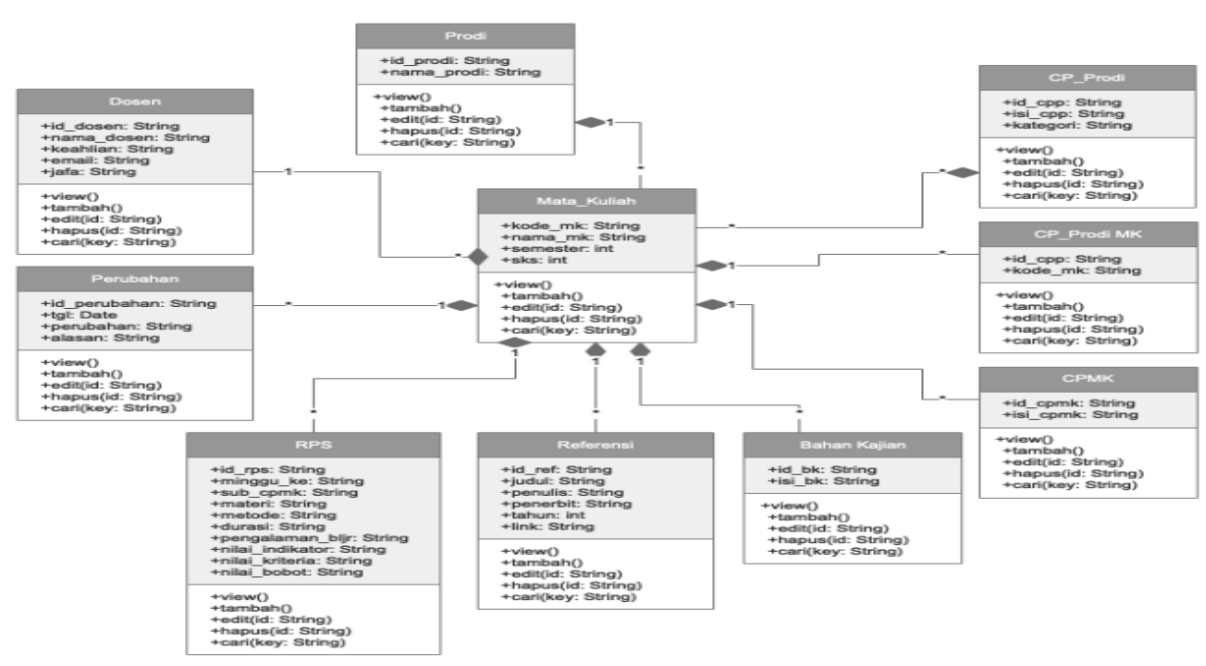

Figure 3 Class Diagram management Information System of RPS

\section{c. Sequence Diagram}

Sequence diagrams will describe the interactions between objects sequentially from top to bottom. With a sequence diagram, a series of messages sent and received at each phase can be described. The sequence diagram for managing the data in this system is as shown in Figure 4 below.

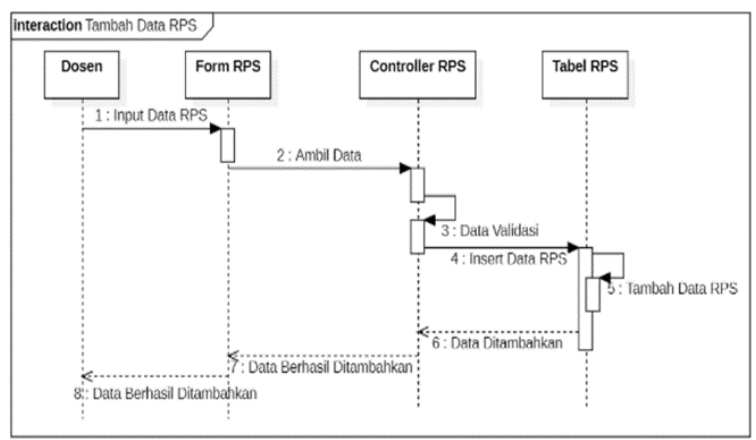

Figure 4 Sequence Diagram Add Data of RPS 


\section{Database Design}

Database design is a reference in data management that will be processed in the system to be built (Prasetyo, 2015). In this database design, several tables have attributes and are related to one another. The form of this relation can be described with an ERD in Figure 5 below.

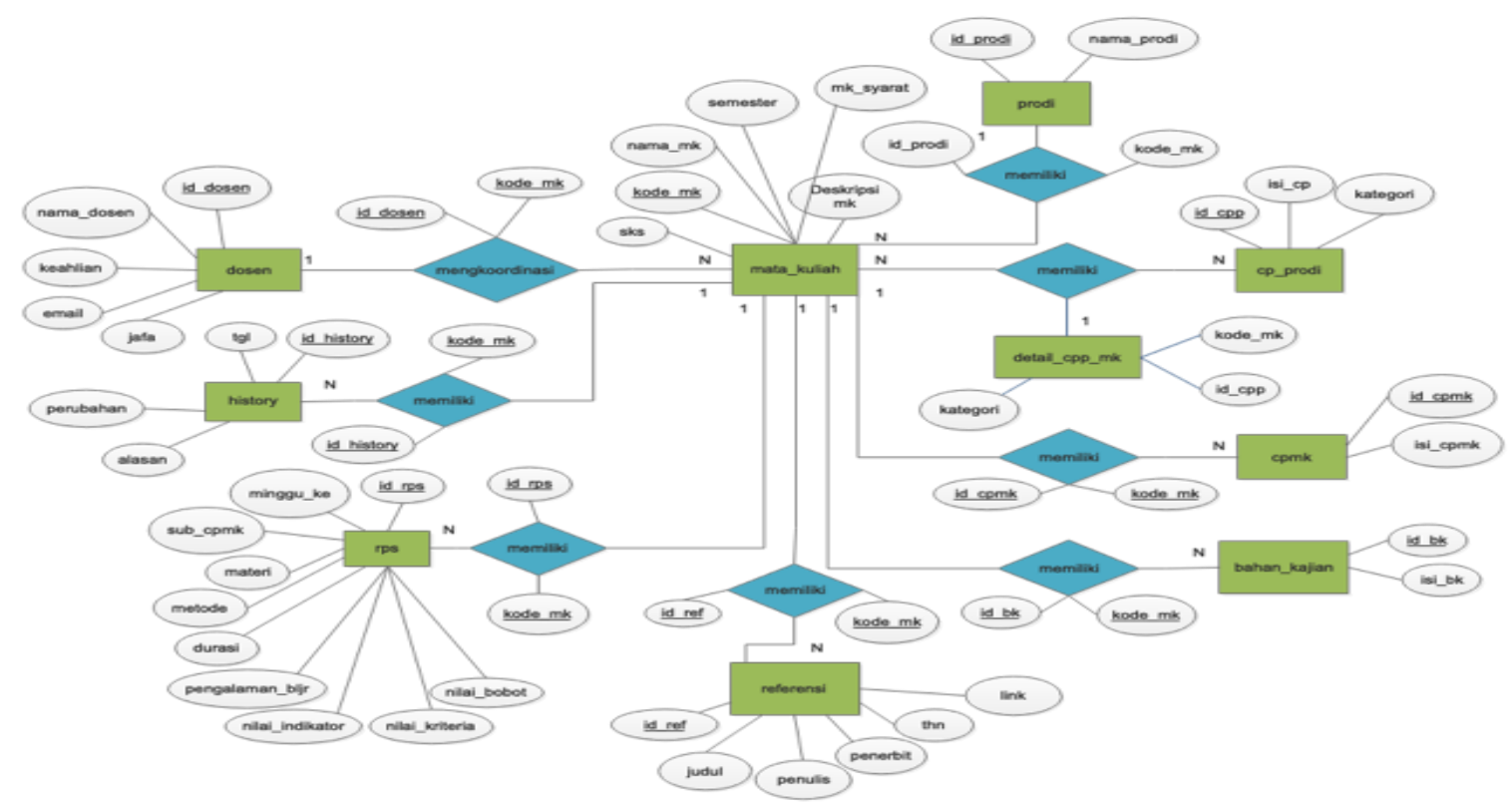

Figure 5. ERD Management Information System of RPS

\section{System Architecture Design}

The following is an overview of the RPS Management Information System Architecture Design shown in Figure 6.

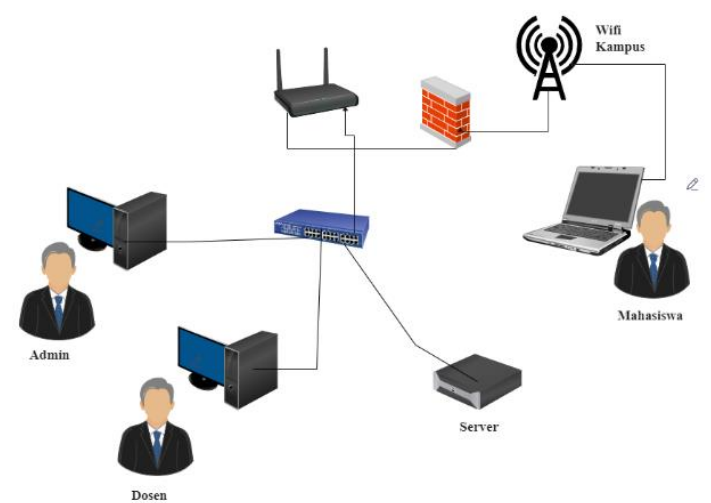

Figure 6 System Architecture Design MIS RPS

\section{Implementation}

This section discusses the results of system analysis and design which is implemented into a Web-based RPS management information system application using MySQL database and CodeIgniter framework 4. The results of the implementation of this system include:

1. Login

The login feature is created using the myth-auth plugin, which is a plugin that functions to regulate the user authentication process based on the type of user and the type of permission. Login will be automatically executed when opening the system, so the user will be asked to enter the user and password to be able to enter the dashboard page as shown in Figure 6.

\begin{tabular}{|l|}
\hline Login \\
Email or username \\
\hline Email or username \\
Password \\
\hline Password \\
\hline \\
\hline Need an account? \\
\hline Forgot your password? \\
\hline
\end{tabular}

Figure 6 Login Page

\section{Dashboard}

On the dashboard page as in Figure 7 below, there are many menus used by the admin to manage all data in the system, such as lecturer data, study program data, course data, study program achievement data, course achievement data, study material data, reference data, RPS data, and RPS change data. 


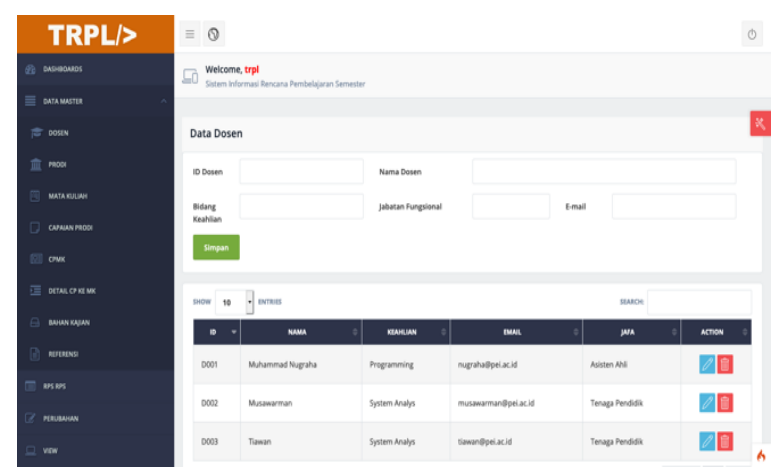

Figure 7 Dashboard Page

\section{Main Page}

The main page is the page used by all users to view the RPS for each course. If the user wants to see the RPS for a certain course, you can select it in the search section and click the search button, the selected RPS will appear as in Figure 8 below.

\section{TRPL/>}
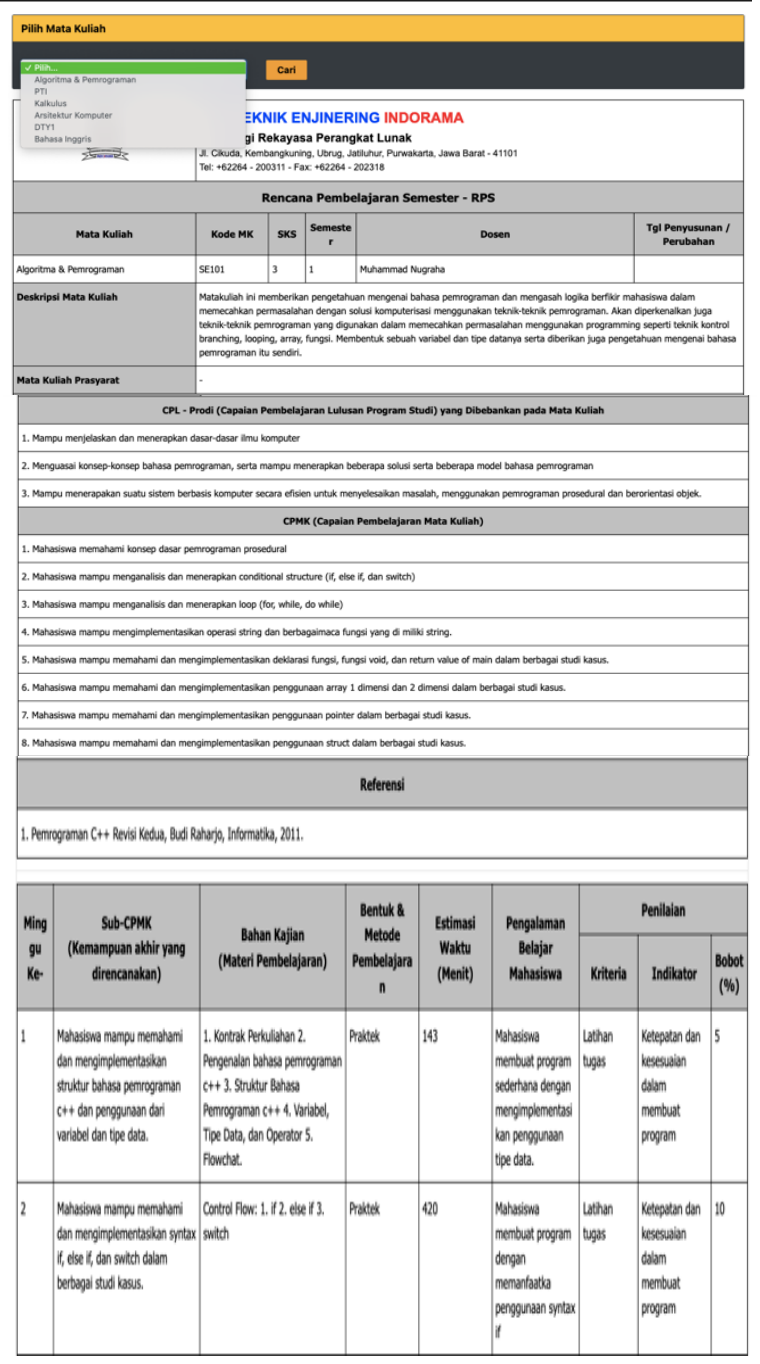

Figure 8 Main Page

\section{Testing}

The first test is done with Unit Testing where the application is tested functionally. Table 1 below is the test results.

Table 1 Black Box Test Result

\begin{tabular}{clc}
\hline No & Description Tested & $\begin{array}{l}\text { Validation } \\
\text { I/0 }\end{array}$ \\
\hline 1 & $\begin{array}{l}\text { Fill in the registered } \\
\text { username and password }\end{array}$ & Valid \\
\hline 2 & $\begin{array}{l}\text { Choose logout then Return } \\
\text { to the login page }\end{array}$ & Valid \\
\hline 3 & Validate Login Data & Valid \\
\hline 4 & Manage Prodi Data & Valid \\
\hline 5 & Manage Lecturer Data & Valid \\
\hline 6 & Manage CPMK Data & Valid \\
\hline 7 & Manage Study Material Data & Valid \\
\hline 8 & View RPS Data & Valid \\
\hline 9 & View Course Data & Valid \\
\hline
\end{tabular}

Furthermore, testing using the Acceptance Test using a Likert scale. From the results of the questionnaire distributed to 50 respondents, the results in table 2 are as follows:

Table 2 UAT Testing Result

\begin{tabular}{lcc}
\hline $\begin{array}{c}\text { Aspects of } \\
\text { Assessment }\end{array}$ & $\begin{array}{c}\text { Present } \\
\text { ation }\end{array}$ & Status \\
\hline Validation & $78 \%$ & Good \\
\hline Function & $86 \%$ & Very good \\
\hline Usability & $88 \%$ & Very good \\
\hline System performance & $81 \%$ & Very good \\
\hline Interface & $85 \%$ & Very good \\
\hline
\end{tabular}

\section{E. Maintenance}

In this stage, the system maintenance process is carried out based on feedback or bug reporting from users during the use of the system. The system is stored on a local server where in terms of performance it has high speed because it is local and incapacity has good capacity and specifications and is young to upgrade. For easy access from outside users can access using agency subdomains or Public IP from instances.

\section{CONCLUSION}

Based on the results of the research that has been done, it is concluded that this web-based RPS management information system can run as needed and can have a good impact on various parties related to managing and accessing RPS data. With this system, users will find it easier and faster to access RPS data information and the manager will be easier and more organized in its management. 


\section{REFERENCE}

APTIKOM. (2018). Pengembangan Kurikulum KKNI Berdasarkan OBE Bidang Ilmu Informatika dan Komputer. APTIKOM.

Gharajeh, M. S. (2019). Waterative model: An integration of the waterfall and iterative software development paradigms. Database Systems Journal, 10, 75-81. Retrieved from http://www.dbjournal.ro/archive/30/30.pdf \#page=75

Government Regulations. (2013). Education National Standar.

Husaini, M. (2019). Pemanfaatan Teknologi Informasi Dalam Bidang Pendidikan (Eeducation). MIKROTIK: Jurnal Manajemen Informatika, 2(1), 1-5. https://doi.org/10.31219/osf.io/ycfa2

Indera, I., Saleh, S., \& Kristian, A. (2020). Pengembangan Desain Sistem Rencana Pembelajaran Semester Jurusan Sistem Informasi. Prosiding Seminar Nasional Darmajaya, 1, 1-8. Lampung: LP4M Institut Informatika Dan Bisnis Darmajaya. Retrieved from https://jurnal.darmajaya.ac.id/index.php/PS ND/article/view/2459

Indrawan, Y. A. A. (2019). Perancangan Sistem Informasi Instrumen Kurikulum dan Evaluasi RPS Studi Kasus: Program Studi Sistem Informasi. KURAWAL Jurnal Teknologi, Informasi Dan Industr, 2(1), 12-22.

Jorgensen, P. C. (2018). Software testing: a craftsman's approach. CRC press.

Kramer, M. (2018). Best Practices in Systems Development Lifecycle: an Analyses Based on the Waterfall Model. Review of Business and Finance Studies, 9(1), 77-84. Retrieved from https://papers.ssrn.com/sol3/papers.cfm?ab stract_id=3131958

Marthasari, G. I., \& Hayatin, N. (2017). Analisis Usability Terhadap Sistem Lective Gegulang Berbasis USE Questionnaire. Prosiding SENTRA (Seminar Teknologi Dan Rekayasa), (3), 1-8. Malang: Fakultas Teknik Universitas Muhammadiyah Malang. Retrieved from http://researchreport.umm.ac.id/index.php/sentra/article/v iew/1458
Muhsinin, U., \& Fatmawati, K. (2020). Validitas dan Praktikalitas Rencana Pembelajaran Semester (RPS) Terintegrasi Research Based Learning. Jurnal Ilmiah Universitas Batanghari Jambi, 20(1), 201-206. Retrieved from http://ji.unbari.ac.id/index.php/ilmiah/articl e/view/791

Munawar. (2018). Analisis Perancangan Sistem Berorientasi Objek Dengan UML. Informatika.

Nurdin, S. (2018). Pengembangan Kurikulum dan Rencana Pembelajaran Semester (RPS) Berbasis KKNI di Perguruan Tinggi. Murabby: Jurnal Pendidikan Islam, 1(2), 140-147. https://doi.org/10.15548/mrb.v1i2.305

Prasetyo, H. N. (2015). Perancangan Dan Implementasi Basis Data (Jilid 1). Deepublish.

Rasimin. (2018). Metode Penelitian Pendekatan Praktis Kualitatif. Jakarta: Mitra Cendikia.

Regulation of the Minister of Education. (2014). Higher Education National Standards.

Regulation of the Minister of Research Technology and Higher Education. (2016). Higher Education Quality Assurance System.

Roman, A. (2018). Black-Box Testing Techniques. In A Study Guide to the ISTQB®Foundation Level 2018 Syllabus (pp. 25-60). Springer.

Sagala, H. S. (2013). Silabus Sebagai Landasan Pelaksanaan Dan Pengembangan Pembelajaran Bagi Guru Yang Profesional (Vol. 5). Retrieved from http://digilib.unimed.ac.id/id/eprint/714

Sarosa, S. (2017). Metodologi Pengembangan Sistem Informasi. INDEKS.

Sitepu, B. P., \& Lestari, I. (2018). Pelaksanaan rencana pembelajaran semester dalam proses pembelajaran di perguruan tinggi. Perspektif Ilmu Pendidikan, 32(1), 41-49. Retrieved from http://journal.unj.ac.id/unj/index.php/pip/a rticle/view/6697

Sugiarti, Y. (2013). Analisis Dan Perancangan UML (Unified Modeling Language). Graha Ilmu.

Sugiyono, S. (2010). Metode penelitian kuantitatif dan kualitatif dan $R \mid \& D$. Alfabeta Bandung.

Syafarina, G. A., \& Setiawan, A. (2019). Perancangan Aplikasi Rencana Pembelajaran Semester (RPS) Untuk Meningkatkan Pencapaian 
Pembelajaran bagi Dosen. Technologia: Jurnal Ilmiah, 10(4), 202-206. Retrieved from https://ojs.uniska-

bjm.ac.id/index.php/JIT/article/view/2362

Wicaksono, G. W. (2015). Lective: Desain Perangkat Pembelajaran Online. Prosiding SENTRA (Seminar Teknologi Dan Rekayasa), (1), 75-80. Malang: Fakultas Teknik Universitas
Muhammadiyah

Malang. https://doi.org/10.22219/sentra.v0i1.2049

Yunianto, T. (2021). Pengembangan RPS-Flip Builder Untuk Meningkatkan Pemahaman Ipa Dalam Pembelajaran Di Masa Covid 19. Jurnal Fundadikdas (Fundamental Pendidikan Dasar), 4(1), 1-8. 